IJCOM 2021 November;1(2):107-13

\title{
Diabetes Mellitus Among Workers Exposed to Perfluorooctanoic Acid
}

Spadini Putri ${ }^{1}$, Muhammad Ilyas ${ }^{2^{*}}$

${ }^{1}$ Occupational Medicine Specialist Program, Department of Community Medicine, Faculty of Medicine Universitas Indonesia

${ }^{2}$ Division of Ocupational Medicion, Department of Community Medicine, Faculty of Medicine Universitas Indonesia

*Corresponding address: Muhammad Ilyas

E-mail: Muhammadilyas@ui.ac.id

\begin{abstract}
Background: One of the health problems that can be caused by Perfluorooctanoic acid (PFOA) is Diabetes mellitus (DM). However, the causal relationship between Perfluorooctanoic acid and DM is still unclear, so it is necessary to look for some evidence regarding this relationship. The search for evidence is also equipped with a seven-step assessment of occupational diseases therefore it can assist occupational health doctors who find patients with DM and have a history of exposure to glutaraldehyde.

Methods: Literature search using Pubmed, Cochrane and JSTOR databases. The keywords used are "PFOA" OR "perfluoroalkyl substances" OR "perfluorooctanoic acid" AND "diabetes mellitus". Article selection was performed using the defined inclusion and exclusion criteria. Selected articles will be critically reviewed based on etiological studies from the Oxford Center of Evidence-Based Medicine.

Result: It was in 5 selected articles that met the inclusion and exclusion criteria. The main finding after a critical review was that PFOA may increase the risk of DM.

Conclusion: There is a relationship between PFOA and the incidence of DM in health workers. To establish the diagnosis of occupational diseases in health workers who are exposed to PFOA, seven steps of diagnosis of occupational diseases are used.

Key words: perfluorooctanoic acid, Diabetes mellitus, occupational diseases
\end{abstract}

\begin{abstract}
Abstrak
Latar belakang: Salah satu masalah kesehatan yang dapat ditimbulkan oleh Perfluorooctanoic acid (PFOA) adalah Diabetes mellitus (DM). Tetapi hubungan sebab akibat antara PFOA dan DM masih belum jelas sehingga untuk itu perlu dicari beberapa bukti mengenai hubungan tersebut. Pencarian bukti juga dilengkapi dengan penilaian tujuh langkah penyakit akibat kerja sehingga dapat membantu dokter kesehatan kerja yang mendapatkan pasien dengan DM serta memiliki riwayat terpajan PFOA.

Metode: Pencarian literatur menggunakan basis data Pubmed, Cochrane dan JSTOR. Kata kunci yang digunakan "PFOA" OR "perfluoroalkyl substances" OR "perfluorooctanoic acid" AND "diabetes mellitus". Pemilihan artikel dilakukan dengan menggunakan kriteria inklusi dan eksklusi yang telah ditentukan. Artikel yang terpilih akan ditelaah secara kritis berdasarkan studi etiologi dari Oxford Centre of Evidence-Based Medicine. Hasil: Didapatkan lima artikel terpilih yang memenuhi kriteria inklusi dan eksklusi. Temuan utama setelah dilakukan telaah secara kritis bahwa PFOA dapat meningkatkan risiko DM.

Kesimpulan: Ada hubungan antara pajanan PFOA dengan kejadian DM pada petugas kesehatan. Untuk menegakkan diagnosis penyakit akibat kerja pada petugas kesehatan yang terpapar PFOA digunakan tujuh langkah diagnosis penyakit akibat kerja.

Kata kunci: perfluorooctanoic acid, diabetes mellitus, penyakit akibat kerja
\end{abstract}




\section{Introduction}

Perfluorooctanoic acid (PFOA) is a man-made chemicals that have been widely used since the 1950s in household and industrial products. For more than half a century, these long-chain compounds have been used in a wide range of industrial applications, such as the manufacturing of consumer products, ranging from grease-proof food packing to aqueous firefighting foams and to stain repellents such as Teflon ${ }^{\circledR}$. Subsequently, these ubiquitous contaminants which are environmentally persistent, toxic, and bioaccumulative, have been a focus of public concern worldwide. Hence, due to public health apprehensions and environmental risks posed by PFOA, their manufacturers and various environmental agencies decided on restricting their use, and whereby the use of these chemicals could not be stopped, their replacement by other alternative chemicals was suggested. Therefore, alternatives to long-chain PFOA was suggested, i.e. to replace the compounds with shorter per - or polyfluorinated carbon chains, e.g. perfluorobutane sulfonate (PFBS), which has been regarded as one of the most important shortchain PFOA and less harmful to the environment at large. However, a systematic review from the current work reveals that physicochemical properties of shortchain PFOA are not different from their predecessors thus suggesting that short-chain PFOA are as harmful as their homologues. ${ }^{1}$

Perfluorinated compounds are a group of organofluorine compounds where fluorine atoms replace all hydrogen atoms. Under this group, PFOA is the most widely used compounds in industrial and consumer products due to their high thermal, oxidative resistance and surface repellence to water and oil. For example, PFOA is used in non-stick cookwares, water and stain proof coatings, protective coatings, and high temperature lubricants. ${ }^{2}$ The commercial applications vary from water and stain resistant coatings in clothes and carpets to coatings for paper, aqueous film forming foams (AFFF), food wrappers, and many others. PFOA were first manufactured by $3 \mathrm{M}$ company adopting Simons Electro-Chemical Fluorination (ECF) process. In this process, a selected organic compound is reacted with hydrogen fluoride in the presence of electric current to replace all the hydrogen atoms in the organic compound with fluorine atoms producing the perfluorinated equivalent. Currently, DuPont is the only PFOA manufacturer in the United States. These compounds can be indirectly produced from the biodegradation of precursors such as fluorotelomer alcohols. ${ }^{3}$

Exposures to these compounds have found to induce reproductive and developmental toxicity and liver toxicity in lab animals. ${ }^{2}$ These compounds are currently listed in Environmental Protection Agency's drinking water Contaminant Candidate List (CCL 3). ${ }^{4} \mathrm{PFOA}$ is environmentally persistent compounds and wide spread use has resulted in global contamination. Trace amounts of these compounds have been found in the environment, human blood and wildlife sample. Drinking water contamination of tap and surface water samples in many countries and trace level detection in oceanwaters have been reported for PFOA., ${ }^{5,6}$ In Australia, drinking water is reported to have $9.7 \mathrm{ng} / \mathrm{lof}$ PFOA. ${ }^{7}$ The lake water in China was reported to have around $5.4 \mathrm{ng} / \mathrm{l}$ of PFOA. Undoubtedly these compounds have posed emerging threat to water quality. ${ }^{5}$ PFOA ranged up to $6.1 \mathrm{ug} / \mathrm{kg}$ dry weight approximately ten times higher than the highest level observed in San Francisco Bay In the USA. Greenpeace investigation found five types of soccer shoes manufactured in Indonesia that contained PFOA, the levels ranged from 5.28-14.5 $\mu \mathrm{g} /$ $\mathrm{m} 2$ for PFOA. To illustrate how significant these levels are, note that the EU regulates PFOS at $1 \mu \mathrm{g} / \mathrm{m}^{2}$ in textiles. The other manufacturing sector in Indonesia, PT Kahatex facilities located near Bandung in West Java PFOA at 12 ppt was found in one sample from the PT. Kahatex factory in the wastewater discharging into the main discharge channel. ${ }^{8}$

The carbon fluorine bond in PFOA is the strongest covalent bond known, making them difficult to be removed by conventional water and wastewater treatment processes. While these compounds can be removed by chemical oxidation under extreme conditions, biological degradation is a desirable option, since biological processes have a potential to degrade these compounds under environmentally relevant conditions. ${ }^{9,10}$

PFOA is persistent environmental contaminants found in the serum of the majority of the human populations studied. PFOA have been linked to adverse health outcomes including birth defects and certain cancers, in the severe cases may be fatal direct contact may cause severe irritation, pain and possibly burns. PFOA long biological half-lives of approximately $3.0-8$ years and their poor ability to metabolize likely 
add to any chronic health effects they may pose, such as chronic kidney disease, diabetes, severe irritation of the respiratory tract with coughing, choking, pain and possibly burns of the mucous membranes, in some cases, pulmonary edema may develop, liver disease, cardiovascular disease, from the physical findings may include moist rales, low blood pressure and high pulse pressure. ${ }^{11}$

Recently, the relationship between PFOA and diabetes has gained great concerns. Insulin level is a crucial indicator for diagnosis of diabetes. Many epidemiological investigations demonstrated significant positive associations between PFOA exposure with $\beta$ cell function, insulin resistance, fasting proinsulin and insulin levels. ${ }^{12}$

From the explanation given above, we know by now that there is a risk of DM in healthy workers who are exposed to PFOA. However, the causal relationship between DM and PFOA remains unclear because health workers are not only exposed to PFOA In this review, some of the evidence implicating PFOA in causing DM will be summarized. In addition, we will also use the seven steps of occupational diagnosis as instituted by Indonesian Occupational Medicine Specialist Association (IOMA) ${ }^{13}$, to help determine whether there is a causal relationship of a disease and work exposure.

\section{Method}

We conducted literature searches using electronic databases, that is, PubMed, Cochrane and JSTOR. The keywords were "PFOA" OR "perfluoroalkyl substances" OR "perfluorooctanoic acid" AND "diabetes mellitus". The inclusion criteria were (1) respondents come from health workers; (2) intervention or exposure is perfluorooctanoic acid; (3) study design were systematic review, meta-analysis, cohort study, case control study and cross-sectional study. The exclusion criteria were non-English articles and inaccessible articles. The search strategy is shown in a flowchart (Figure 1).

The selected literature was critically appraised using relevant criteria with the worksheet for etiology study from Oxford Centre of Evidence-Based Medicine.

\section{Result}

The searching was completed on May $20^{\text {th }}, 2020$. Of the online searches, it resulted in five selected articles that met the inclusion and exclusion criteria. The selected articles consisted of 3 cohort studies by Giovanni Costa et al, 2018, Andres Cardenas et al, 2018, and Conny Karnes et al, 2013, and 2 cross-sectional studies by Xiaowei He et al, 2017, and Jessica MacNeil et al, 2009. ${ }^{10-15}$ glutaraldehyde has many toxic sideeffects, including the ability to induce allergic contact dermatitis. In a 5-year study at the University of Kansas, 468 patients were patch tested to glutaraldehyde. A comparison of results was made between those employed in a health-care related field and those who were not. Health-care workers (HCWs Critical appraisal are shown in Table 1.

\section{Discussion}

We used the seven steps of occupational diagnosis as instituted by $\mathrm{IOMA}^{13}$ in order to determine the relationship between diseases with workers if we found that the workers are with diabetes mellitus exposed to PFOA.

1. Clinical Diagnosis

Diabetes mellitus can be established by anamnesis such as unhealthy diet, a sedentary lifestyle, and family history, have contributed to the rise in the occurrence of diabetes, physical examination, and supportive examination such as laboratory finding to know as serum fasting glucose levels, insulin and C-peptide were measured in the blood samples.

2. Occupational Exposure

Exposure to the PFOA as an environmental pollutants, have a role in improving quality of some products commonly used in our daily living, but their properties of being bioaccumulated in environment induce unexpectedly harmful effects to human health. Humans can be exposed to these chemicals in various ways, including through the food we eat, and the air and dust we breathe indoors and outdoors, including in the work place. Moreover, working in the department where 


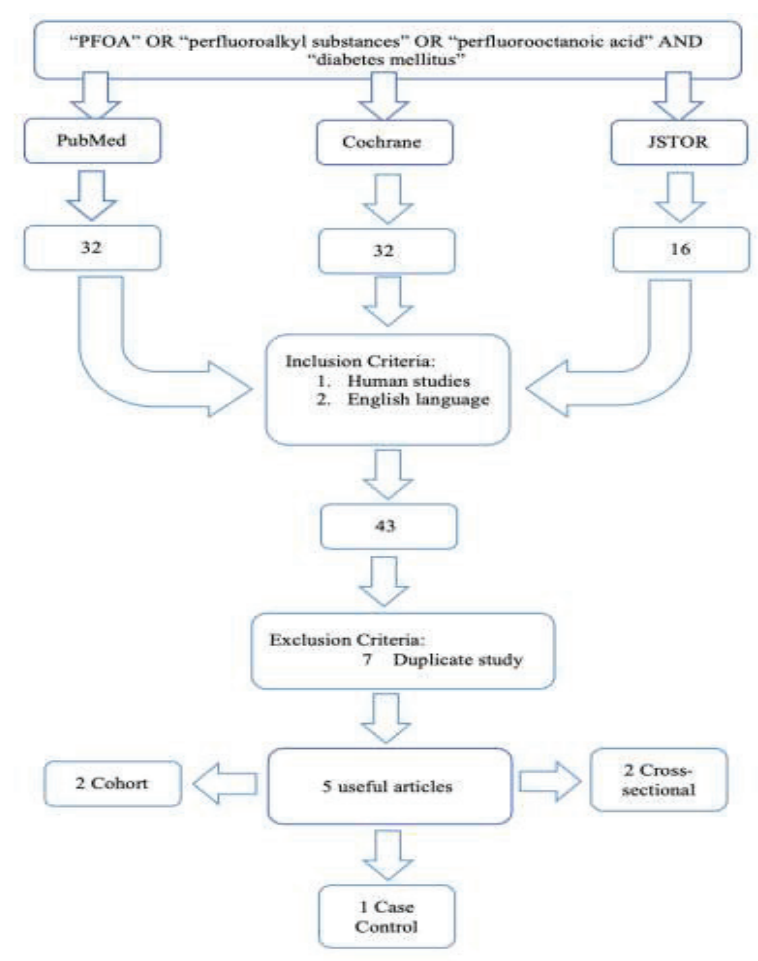

Figure 1. Flowchart of literature search

Tabel 1. The Critical Appraisal of The Study

\begin{tabular}{|c|c|c|c|c|c|c|c|c|c|c|c|}
\hline \multirow[b]{2}{*}{ Articles } & \multicolumn{8}{|c|}{ Validity } & \multicolumn{2}{|c|}{ Relevance } & \multirow[b]{2}{*}{$\begin{array}{l}\text { Level of } \\
\text { Evidence }\end{array}$} \\
\hline & 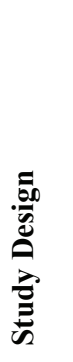 & 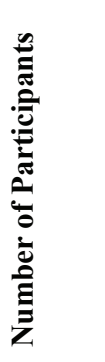 & 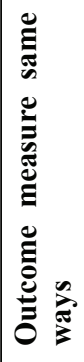 & 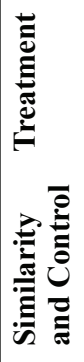 & 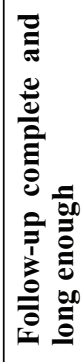 & 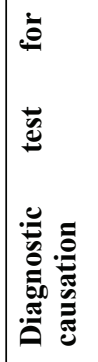 & 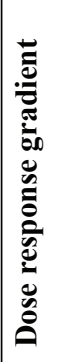 & 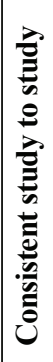 & 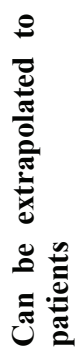 & 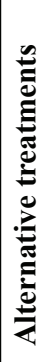 & \\
\hline $\begin{array}{l}\text { Giovanni Costa, MD Samantha Sartori, et } \\
\text { al (2018) }\end{array}$ & $\mathrm{CH}$ & 53 & + & - & + & - & + & - & + & - & $2 b$ \\
\hline $\begin{array}{l}\text { Andres Cardenas, Marie France Hivert, et } \\
\text { al (2018) }\end{array}$ & $\mathrm{CH}$ & 957 & + & - & + & + & + & + & + & + & $1 b$ \\
\hline $\begin{array}{l}\text { Conny Karnes, Andrea Winquist, et al } \\
(2013)\end{array}$ & $\mathrm{CH}$ & 32.254 & + & - & + & + & + & + & + & - & $2 b$ \\
\hline Xiaowei He, Yuanxin Liu, et al (2017) & $\mathrm{CS}$ & 7.904 & + & - & - & + & + & - & + & - & $2 b$ \\
\hline $\begin{array}{l}\text { Jessica MacNeil, N. Kyle Steenland, et al } \\
\text { (2009) }\end{array}$ & $\mathrm{CS}$ & 54.468 & + & - & - & + & + & - & + & - & $2 b$ \\
\hline
\end{tabular}

Note: + stated clearly in the article; - not being done; ? not stated clearly; $\mathrm{CH}=$ Cohort; $\mathrm{CS}=$ Cross sectional 
there is higher exposure of PFOA were found to be more risky. To investigate the amount of PFOA in the environment, surveillance should be done by measure PFOA levels in soil and water near the wasteland or wastewater. Beside that, biomonitoring also should be done to investigate the human effect of PFOA, such as measurement of association between PFOA and biomarkers of glycaemic status as serum fasting glucose levels, insulin and C-peptide were measured in the blood samples. ${ }^{22}$

The challenges of managing PFOA in Indonesia is none of the national agencies in Indonesia have any program for environmental monitoring of PFOA. Program to monitor impact of PFOA to human health does not exist either. Reasons for this could be due lack of regulations on it, low capacity of laboratory infrastructure and human resources and the high cost of laboratory sampling and analysis. However, the presence of PFOA in human and biota from Indonesia have been noted by monitoring studies of foreign researchers such as a services that are available for PFOAs testing are private laboratories, under the umbrella of a multinational laboratory company. Samples delivered to these laboratories for PFOA analysis will require sending them out to a laboratory within their parent company in another country; usually Australia or Singapore, creating high costs to test PFOA. The national bureau has the capacity and laboratory equipment but does not have the standards needed to measure PFOA. Only qualitative parameters for PFOA are available.

3. Evidence That PFAO Can Cause Diabetes Mellitus

Bradford Hill criteria is used to determine whether there is sufficient evidence that PFOA can cause Diabetes Mellitus:

Strength of association

Diabetes Mellitus due to PFOA exposure is still unclear, some study mention that Diabetes Mellitus due to PFOA exposure is corelate but some study not

Consistency:

Result from this systematic study is still not consistent, similar outcome (Diabetes Mellitus) was found at different places and years in the study, but there are some study that negatively corelate.

Specificity:

Higher plasma concentrations of PFOS and

PFOA were not specifically associated with an elevated risk of type 2 Diabetes, because there are another risk factors, including body mass index, family history, physical activity that is corelate to DM type 2, manifestation.

Temporality:

Higher plasma concentrations of PFOS and PFOA were not specifically associated with an elevated risk of type 2 Diabetes. The $5^{\text {th }}$ journal trying to explain the association between degree of pfoa exposure measured from serum pfoa level indicating previous dose exposure and the outcome of type ii diabetes, but because of it's design we couldn't rule out the confounding factors causing diabetes.

Dose response:

Based on articles that I used in this systematic review. Andres Cardenas et al, reported some plasma PFASs were associated with diabetes, Xiaowei He et al, reported the levels of serum PFOA may be positively associated with the prevalence of diabetes in men, Conny Karnes et al and Jessica MacNeil et al reported there are no association between PFOA and either type II diabetes or fasting glucose level and the last journal reported by Giovanni Costa et al a probable interference of PFOA on intermediate metabolism is still deserves further investigations. There are no dose response threshold were reported.

Coherent:

Different types of evidence from different studies support cause-effect interpretation, but there are some evidence that have different conclusion.

Experiment: -

Analogy: -

4. Sufficiency of Exposure

Both ACGIH and OSHA so far have not determined the threshold value for TLV and PEL for occupational, but from Environmental Protection Agency (EPA) set up threshold for 
national drinking water regulation is $2 \times 10^{-5} \mathrm{mg} /$ $\mathrm{kg} /$ day or $0.07 \mu \mathrm{g} / \mathrm{L}$, but there is no evidence in foods.

5. Individual factors

PFOA have been produced since the late 1940s, and because of their unique properties, including thermal stability, hydrophobicity, and oleophobicity, they have been used in nonstick cookware, oil- and water-resistant textiles, greaseproof food packaging, surfactants, firefighting foams, pesticides, cosmetics, and construction and electronic products, among other applications. Human exposure from direct and indirect sources, including contaminated food and drinking water, is pervasive. Some PFOA are readily absorbed in the body, bind to serum proteins, and have small-to-negligible renal clearance, accumulating in organs such as the liver and also associated with diabetes incidence and microvascular disease during 15 years of average follow-up but that the initial lifestyle intervention would attenuate these associations.

6. Other factors

PFOA can be released into the environment and contaminate soil, gas, and also water. Many studies said that PFAO is environmentally persistent and slowly excreted from the human body. Study mention that PFOA is found in small quantities in the serum of $95 \%$ of US population $(4 \mu \mathrm{g} / \mathrm{L})$.

7. Resume

Five peer reviewed studies in scientific journals above have examined the relationship between PFOA, diabetes, surveillance and biomonitoring. The human epidemiological studies have on PFOA and diabetes have been mixed, with some finding found that people with higher exposures to PFOA have a higher risk of diabetes, while others do not. Laboratory studies on animals or cells show that PFOA exposures can cause biological effects related to diabetes, and have helped to identify the key periods of susceptibility and the mechanisms. The strongest evidence for the ability for environmental exposures to contribute to the development of diabetes comes from Cardenas et al. 2017. In the U.S. Diabetes Prevention Program, PFOS and
PFOA were associated with insulin resistance, beta cell function, and HbA1c. Yet after 4.6 years of follow-up, these chemicals did not appear to affect the incidence of diabetes or changes in these markers. However, further research of this group shows that some PFAS levels were associated with the long-term development of type 2 diabetes-- but only in people who did not participate in the diet/ exercise program. (Some PFOA were associated with microvascular disease development, even in people who did lifestyle changes). Also in this group, adults at high risk for diabetes with higher PFOA levels had higher increases in weight and hip girth over time, but a lifestyle intervention reduced these associations. These studies illustrate that diet and exercise may mitigate the obesogenic and diabetogenic effects of environmental chemicals. The evidence is still growing, even though there are a journal of PFOA was associated with a higher risk of being diabetes its provide weaker evidence of the workers community.

\section{Conclusion}

To determine the causal relationship, we conducted critical appraisal using the Evidence-Based Medicine etiology study worksheet and Austin Bradford Hill's criteria, which suggested a relationship between the use of PFOA and the incidence of DM in a workers. PFOA is human made chemical and environmentally persistent, slowly excreted from the human body is can be released and contaminate the environment. PFOA is resistant to degradation and persists indefinitely in the environment. PFOA is not metabolized, and has their long biological half-lives of approximately 3.0-8 years. The evidence is still growing, even though there are a journals of PFOA was associated with a higher risk of being diabetes its provide weaker evidence of the workers community.

After all, we recommend five step recommendations at work for PFOA exposure such as; health promotion, do the health promotion programs aim to engage and empower individuals and communities to choose healthy behaviors, and make changes that reduce the risk of developing chronic diseases and other morbidities such as avoid the sources of PFOA as long as you can 
and avoid using everything that contained PFOA. Specific protection, use proper PPE such respirator mask, chemical resistant gloves, safety google and face shield. Early diagnosis and prompt treatment, do regular medical checkup of all PFOA workers should be done to early detection of side effects, laboratory finding to know impaired fasting glucose level, insulin, c peptide, liver function, kidney function, chest X-ray, ECG and spirometry. Disability limitation of PFOA effects by reducing occurrence of impairment, treatment, and prevent transition to diability. The last step is rehabilitation, it is important to set the interventions needed when a worker is experiencing or is likely to experience limitations in everyday functioning due to PFOA effects.

\section{References}

1. Wang T, Wang Y, Liao C, Cai Y, Jiang G. Perspectives on the Inclusion of Perfluorooctane Sulfonate into the Stockholm Convention on Persistent Organic Pollutants. Environ Sci Technol. 2009 Jul 15;43(14):5171-5.

2. Begley TH, White K, Honigfort P, Twaroski ML, Neches R, Walker RA. Perfluorochemicals: potential sources of and migration from food packaging. Food Addit Contam. 2005 Oct;22(10):1023-31.

3. 06-2152.pdf [Internet]. [cited 2020 May 18]. Available from: https:/www.govinfo.gov/content/pkg/FR-2006-03-07/ pdf/06-2152.pdf

4. Drinking Water Contaminant Candidate List 3-Final [Internet].
Federal Register. 2009 [cited 2020 May 18]. Available from: https://www.federalregister.gov/documents/2009/10/08/ E9-24287/drinking-water-contaminant-candidate-list-3-final

5. Jin YH, Liu W, Sato I, Nakayama SF, Sasaki K, Saito N, et al. PFOS and PFOA in environmental and tap water in China. Chemosphere. 2009 Oct;77(5):605-11.

6. Yamashita N, Taniyasu S, Petrick G, Wei S, Gamo T, Lam PKS, et al. Perfluorinated acids as novel chemical tracers of global circulation of ocean waters. Chemosphere. 2008 Jan;70(7):1247-55.

7. Thompson J, Eaglesham G, Mueller J. Concentrations of PFOS, PFOA and other perfluorinated alkyl acids in Australian drinking water. Chemosphere. 2011 May;83(10):1320-5.

8. indonesia_pfas_country_situation_report_apr_2019.pdf [Internet]. [cited 2020 May 18]. Available from: https://ipen. org/sites/default/files/documents/indonesia_pfas_country_sit

9. Parsons JR, Sáez M, Dolfing J, de Voogt P. Biodegradation of perfluorinated compounds. Rev Environ Contam Toxicol. 2008;196:53-71.

10. Hori H, Hayakawa E, Einaga H, Kutsuna S, Koike K, Ibusuki $\mathrm{T}$, et al. Decomposition of environmentally persistent perfluorooctanoic acid in water by photochemical approaches. Environ Sci Technol. 2004 Nov 15;38(22):6118-24.

11. Conway BN, Badders AN, Costacou T, Arthur JM, Innes KE. Perfluoroalkyl substances and kidney function in chronic kidney disease, anemia, and diabetes. Diabetes Metab Syndr Obes Targets Ther. 2018;11:707-16.

12. Qin W-P, Cao L-Y, Li C-H, Guo L-H, Colbourne J, Ren X-M. Perfluoroalkyl Substances Stimulate Insulin Secretion by Islet $\beta$ Cells via $G$ Protein-Coupled Receptor 40. Environ Sci Technol. 2020 Mar 17;54(6):3428-36.

13. Indonesia PSK. Pedoman Klinis Diagnosis dan Tatalaksana Kasus Penyakit Akibat Kerja. 